Available online at: https://specedjournal.aspu.am/index.php/se

DOI: $10.24234 /$ se.v5i1.289

\title{
ANALYSIS OF PARENTAL AWARENESS REGARDING THE ROLE OF ART THERAPY IN THE DEVELOPMENT OF CHILDREN WITH COMPLEX MULTIPLE DISABILITIES
}

\author{
AUTHORS' DATA: \\ Svetlana Muradyan, $\mathrm{PhD}$ in Education, Associated professor \\ Chair of Special Pedagogy and Psychology, \\ Khachatur Abovyan Armenian State Pedagogical University, Republic of Armenia \\ Lecturer, Deputy dean for science and international cooperation \\ Contacts: muradyansvetlana41@aspu.am \\ Amalya Gabrielyan, MA \\ Psychologist \\ Regional pedagogical-psychological support centre N2, Republic of Armenia \\ Contacts: gabrielyanamalya-9@aspu.am
}

\begin{abstract}
Emphasizing the need to develop the creative abilities of children with complex, multiple disabilities, within the full implementation of the educational process, both at home and in school, the need to raise the level of awareness of parents in regards the issues under study is greatly emphasized.

This article analyzes the level of awareness of parents about the developmental role of art therapy, the existing problems, as well as the concerns parents have.

In the frame of the current research the quantitative research is use for collecting and analyzing numerical data. It is called to make predictions, and generalize results to wider populations.

The results of the presented research prove the role of the parent, and the family in general in the further development of the child, ensuring the full-fledged educational process. In this context, it is considered extremely important to ensure the level of awareness of parents about the current approaches to the implementation of the educational process of children and their further development.
\end{abstract}

Key words: art therapy, children with complex and multiple disabilities, parents, creative abilities, development. 


\section{INTRODUCTION}

Art therapy is a modern branch of psychotherapy, based on the principle of creative self-expression. The name itself tells us the meaning of the term. Art therapy is nothing but therapy based on and including different art avtivities. One can describe that it is a developing field based on psychology on the one hand and art on the other, which has found its wide application in the modern world (Kisileva, 2006; Yermolaeva, 2001; Kopitin, 1999). In order to develop the creative abilities of children with complex multiple developmental disorders through art therapy, which acts as a means of developing the creative abilities of children with complex developmental disorders, it is important to analyze the level of awareness of parents in regards of the therapy.

\section{LITERATURE REVIEW}

The analysis of scientific-methodological literature (Kopitin, 2016; Lyashenko, 2014) proves the important role and significance of art and psychological therapy in the process of child development. This direction of psychological support, which appeared in the middle of the last century, took its unique place in the world of psychology and related fields, an continue spreading more and more all over the world and in Armenia. Mostly, literature on art therapy and disability is conquered by the perspectives of therapists who are non-disabled, so far hold the position of expert in relation to people with mental illness or disabilities (Hewitt-Parsons, 2021).

At the beginning of the 20th century, the famous Swiss psychologist Carl Gustav Jung began to use mandalas as a tool to study his own personality. Every day he kept a diary in which he outlined his emotional state in a symbolic way. Most often, these drawings looked like rings. In the field of art therapy, mandala therapy is widely used today as a means of restoring mental harmony and integrity. Mandala (translated from Sanskrit means circle) and mandala therapy is the application of a picture taken in a circle (Slegelis, 1987).

Art therapy has been introduced in the United Kingdom since 1999 and is central to supportive activities in health related fields. In contrast to the United Kingdom, art therapy is generally not widely practiced in Colombia; here therapists are generally trained abroad. In the United Kingdom, on the other hand, art therapy is thought out and planned within the framework of health programs (see Art therapy and online world). At present, art therapy is used not only in hospitals, psychiatric centers, but also in a number of other centers as a form of self-therapy, as well as a continuation of a number of group therapies. A number of art therapy professionals in North America continue to work based on Freud and Jung's concepts. A number of experts in this field have felt the great influence of humanistic psychology and have 
come to the conclusion that humanistic theories provide greater accuracy in their work than psychoanalytic theories (Kil, 2004).

However, the art therapy arena has long provided services for people with disabilities, it has not fully engaged with the multiple and complex conditions that lead to full social exclusion, mental distress, and discrimination (Hewitt-Parsons, 2021).

The arts therapy engages people in creative interventions to address clinical goals in numerous domains and improve overall well-being and functioning. From this scope it is more than important while reflecting children with complex multiple developmental disorders. Because of their difficulties in adaptability, art therapy helps to focus on motor, communication, psychosocial, cognitive and emotional goals (Ahessy, 2020). Art therapy are resource-based and concentrate on what children can do, promoting independence taking into consideration the fact of child's ability and level of participation. At the same time according to research results conducted in Hong Kong it is stated that expressive art therapy intervention has different effects on the emotional and behavioral well-being of male and female participants (Ho, Chan, Fong, Lee, Lum, \& Suen, 2020). This point might be more brightly seen while we talk about children with multiple disabilities.

It is noteworthy that starting from 2018, in Republic of Armenia, the regional pedagogical and psychological support centers were established, to provide complex services to children with special educational needs based on the parents' application. The centers provide various services: support, evaluation, and consulting to children with educational needs. The provision of services to the child in the regional center is provided free of charge, with the funds of state. Then, at any stage of education, if the child has persistent difficulties that prevent the child from participating in the learning process to the best of his/her ability, the evaluation phase begins, which includes a study of the results of observation of the child's parent, teachers, and psychologists. Within tis frame od services art-therapy is also included as intervention men and can be provided by, occupational therapists, art0therapista, speech therapist and psychologists.

Based on the data provided by different sources of the scientific-methodological literature, the results of practical activities and the above-mentioned assertions, the main purpose of this study is to reveal the level of awareness of parents of children with multiple developmental disabilities within the scope of art therapy intervention.

\section{METHOD}

As a basis of the study, the survey was selected the main method from all other Psychopedagogical methods, which has been used in the combination of parents of children with 
complex and multiple disorders. In this context, individual questionnaires consisting of 15 questions were prepared in advance. The survey was conducted anonymously. The priority of the analysis of the questions presented below was mainly used in the questionnaires. The main purpose of the survey is to find out the level of parents' awareness and ideas about art therapy in the process of developing the creative abilities of children with complex and multiple disorders through a questionnaire.

The was conducted with the parents of children with complex and multiple disorders visiting Yerevan school No. 162, Yerevan School No. 192, and Yerevan No. 2 regional Pedagogical-Psychological Support Center children with complex and multiple disorders. Twenty parents participated in the survey. 18 parents from 20 who took part in the survey had higher education.

\section{RESULTS}

According to the question, are they familiar with art therapy as a therapeutic tool for developing the creative abilities of children with complex, multiple disorders? $65 \%$ of parents surveyed answered yes, $25 \%$ answered no, and $10 \%$ found the question difficult to answer.

At the same time to the question, if parents consider important the use of art therapy in works aimed to develop the creative abilities of children with complex and multiple disorders? Results indicate that $60 \%$ of the parents who took part in the survey gave a positive answer, and $40 \%$ found it difficult to answer the question.

It is noteworthy that all the parents who took part in the survey consider important the use of art therapy to develop the creative abilities of children with complex and multiple disorders.

To the question, do specialists perform art therapy in classes with children with complex or multiple disorders? About 55\% of the parents who took part in the survey answered positively, and $45 \%$ found it difficult to answer the question.

\section{Figure 1.}

According to the parents who participated in the survey: The effectiveness of art therapy services provided by specialists in the development of creative abilities in children with complex or multiple disabilities. 


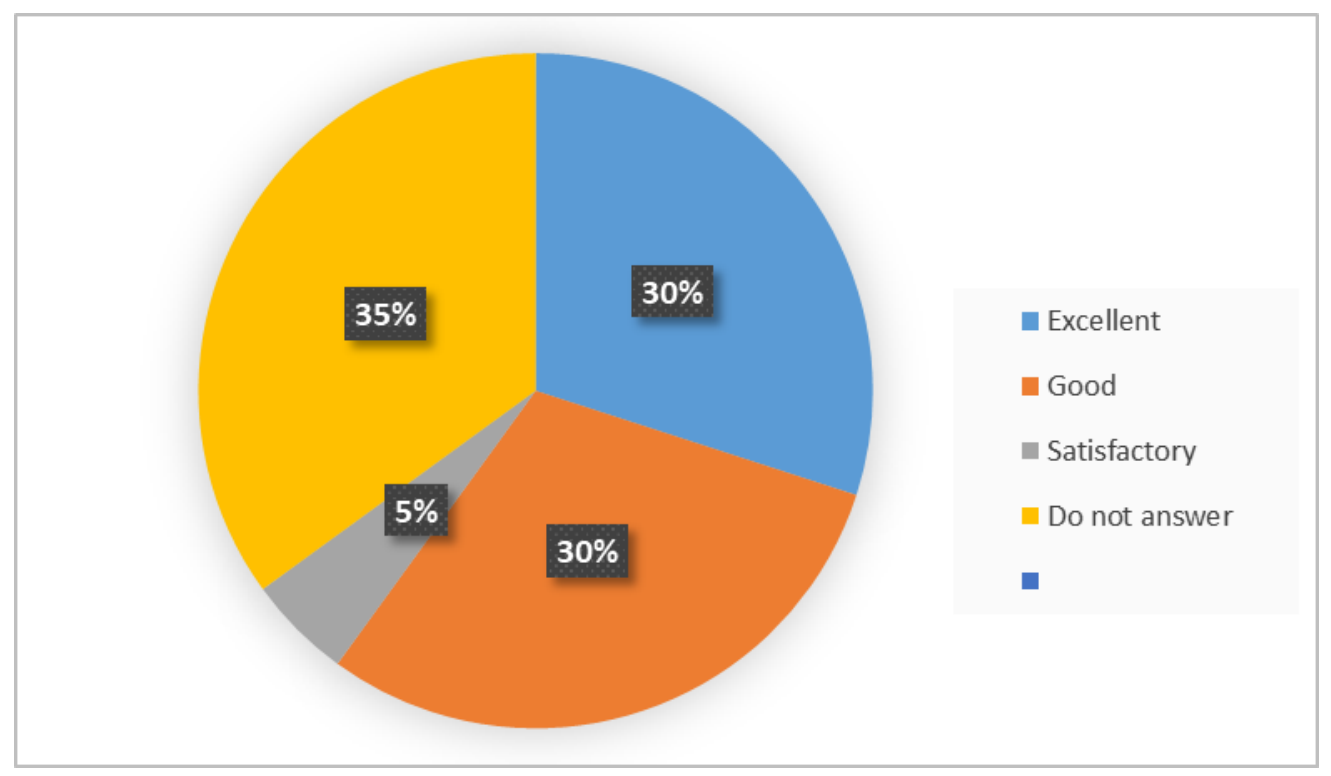

And to the question of how they evaluate the effectiveness of the art therapy provided by specialists in the work aimed to develop the creative abilities of children with complex or multiple disabilities?

At the same time, $30 \%$ of the parents who took part in the survey answered excellently, $30 \%$ - well, 5\% - satisfactorily, and 35\% did not answer the question (Figure 1).

Then, to the question of in what period and format the specialists mentioned arttherapeutic works, answered only 18 parents from 20 who took part in the survey, according to which $67 \%$ mentioned during individual training, $23 \%$ - during free time, 5\% - during school classes, and the other 5\% - during non-formal classes or extracurricular activities (Figure 2).

\section{Figure 2.}

The result of a parent survey on the issue of performing art therapy with children with complex and multiple disorders.

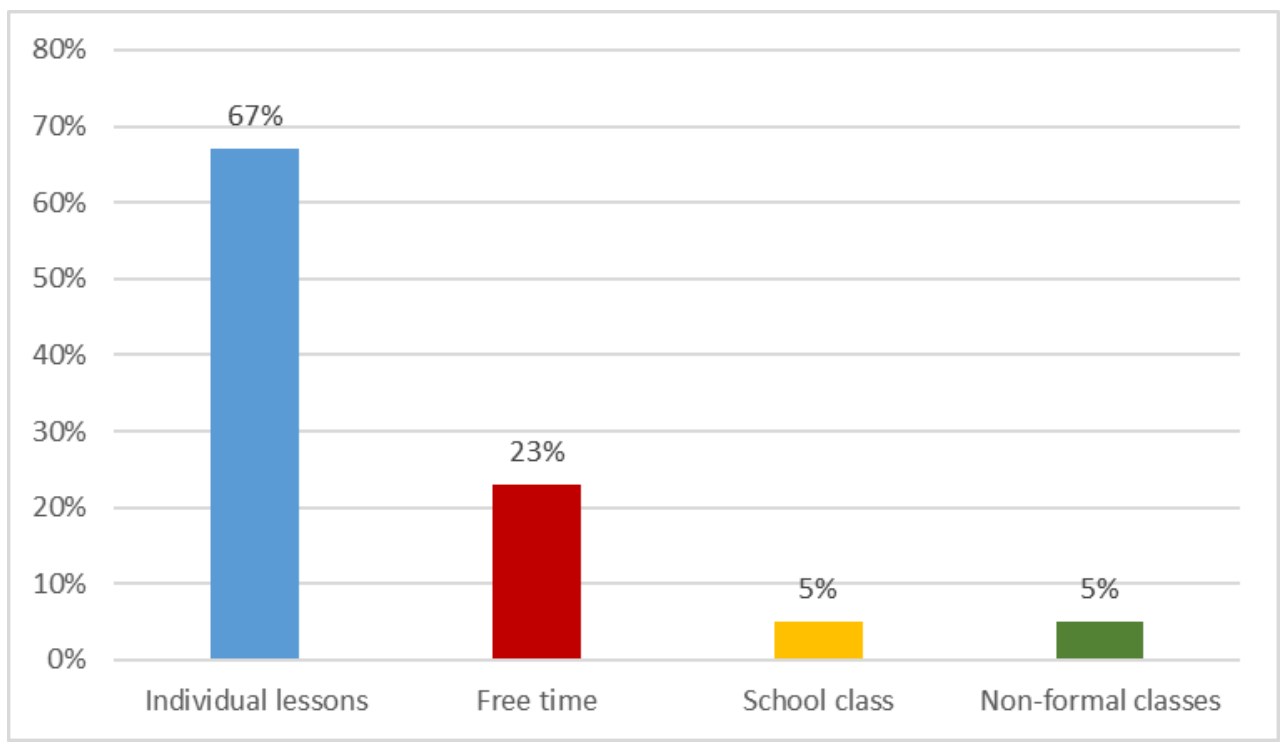


To the question, what measures do professionals use to develop the creative abilities of children with complex or multiple disabilities? Most of the parents consider important the use of music therapy, puppet therapy, dance therapy, caviar therapy, sand therapy, fairy tale therapy, painting therapy, bibliotherapy.

To the last question, if they have any concerns or suggestions about how to develop the creativity of children with complex or multiple disabilities, most of the parents mentioned the following:

- Provide information about art therapy;

- Use artwork more often by the specialists;

- Presence of specially equipped rooms for art therapy sessions;

- Ensuring continuous use of art therapy;

- Ensuring the diversity of applicable tools and methods;

- Providing more awareness and information to parents, about art-therapeutic methods and tools.

\section{DISCUSSION}

The above mentioned proves in a way that art therapy, being between the subconscious and conscious, is a connecting bridge between brain and soul. The use of this technique can solve many problems. At the same time, there is a need for parents to provide relevant and accurate information about the use of the toolkit and becomes possible to solve stable, clear problems with children at the level of use art, metaphors and images.

According to the parents who took part in the survey, it can be the best way in the context to normalize relations with their children and to develop artistic abilities and selfesteem.

According to the famous art psychologist Gudmen, whene the term "art" is used, people do not think about words, but they imagine colors, complex feelings, images, lines, etc., which are difficult to express through language. According to the specialist, this is evidence of the complexity of the charm of the profession (Gudmen, 2020). That was kind of understanding of parents while thinking about art therapy influence on their child development.

And according to Keduson, Schaefer's aesthetic feelings always have a transformative effect, and the aesthetic object forms the basis of the transformed experience (Keduson, Shefer 2001). This is exactly what the results of the research prove, analysis of the results of the parents' survey. And so the results of the parents' survey prove the fact that color gives us the warmth of life, feelings, emotions and indescribable nuances of feelings that the intellect is 
unable to distinguish and express. According to the majority of the parents who took part in the survey, the color and musical sound are the direct means of expressing mental feelings, those emotions and feelings that cannot be determined, expressed through the mind. Therefore, according to the parents' testimony, this is one of the modern models of psychologicalpedagogical influence, which in a way provides the emotional connection between the parent and the child. There is simply one problem that arises here, which is due to the mastery of the toolkit for applying the method. After summarizing the results obtained, it is worth to mention some important preconditions that should be provided within the topic:

- Ensuring parents' awareness of art therapy, particularly mandala therapy;

- Providing parents with appropriate tools for the use of art therapy, in particular mandala therapy;

- Providing parents with appropriate scientific and methodological literature and methodological instructions;

- The importance of a child's condition in the context of the use of art therapy, particularly mandala therapy;

- Taking into account the peculiarities of the child's development and age factor in choosing mandalas.

\section{CONCLUSION}

Thus, the results of the parents' survey on the implementation of art-therapeutic work with children with complex, multiple disorders prove, that although the implementation of educational activities with these children is quite widespread today, the need to use the latest approaches, tools and methods, but in some cases, all this is not available to parents. The priority is to equip parents with practical skills in the studied issues, to provide appropriate tools, to raise the level of awareness. To make these practical skills available to parents, consultations and trainings provided for parents by the specialists of the Regional PedagogicalPsychological Support Center are now being organized. In this way, we can inform parents about the potential of art therapy, which can not only be provided by a multidisciplinary team, but they can also participate in these works.

\section{REFERENCE LIST}

1. Ahessy, B. (2020). Creative Arts Therapies in Disability Settings.

2. Elg, G. N Chelovek, igrayushi v pesok. Dinamichnaya pesochnaya terapiya. S.P.b. Rech, 2010. - 208 s. 
3. Gudmen, M. Detskiy risunok: - M.: Muzey sovremennogo iskustva «Garaj», 2020. $-192 \mathrm{~s}$.

4. Hewitt-Parsons, S. (2021). An Other's Perspective: Establishing a Disabled Identity in a Traditional Healthcare Setting (La perspective de l'Autre : établir son identité comme personne handicapée dans un contexte traditionnel de soins de santé). Canadian Journal of Art Therapy 34:2, pages 92-100.

5. Ho, R. T. H., Chan C.K. P., Fong, T.C., Lee, P.H. T., Lum, D. S. Y., \& Suen, S. H. (2020). Effects of Expressive Arts-Based Interventions on Adults with Intellectual Disabilities: A Stratified Randomized Controlled Trial, Psychology in Clinical Settings.

6. Keduson, H. Shefer, Ch. Praktikum po igrovoj psikhoterapii. - SPb.: Piter, 2001. $416 \mathrm{~s}$.

7. Kil, R. (2004) Grupovaya psikhoterapia psikhokorekcionnie grupi: teoriya i praktika. PSYLIB $275 \mathrm{~s}$.

8. Kisileva, M. V. (2006). Art-terapiya v rabote s detmi. Rukovodstvo dlya detskix pshixologov, pedagogov, vrachey i specialistov, rabotayushix s detmi._S.P.b..

9. Kopitin, A. I. (1999). Osnovi art-terapi.-S.P.b. Lan. - 256 s.

10. Kopitin, A. I. (2016). "Didaktika art terapii. Metod "Mandala"" Uchebnoe posobie, Moskva - 144 s.

11. Lyashenko, V. V. (2014). "Art terapiya kak praktika samopoznaniya. Prisutstvovannaya art terapiya". uchebnoe posobie Moskva - $160 \mathrm{~s}$.

12. Yermolaeva, M. V. (2001). Prakticheskaya psikhologiya detskogo tvorchestva: uchebnoe posobie, Moskva: MPSI - 194 s.

13. Arvesti terapia ev arcanc ashxarh: https://hy.perestanovki.org/2553-mandalatherapy.html 